\title{
TNF inhibitor therapy for rheumatoid arthritis (Review)
}

\author{
XIXI MA and SHENGQIAN XU \\ Department of Rheumatology and Immunology, The First Affiliated Hospital \\ of Anhui Medical University, Hefei 230022, P.R. China
}

Received October 3, 2012; Accepted October 16, 2012

DOI: $10.3892 /$ br. 2012.42

\begin{abstract}
Immunotherapy has markedly improved treatment outcomes in rheumatoid arthritis (RA). Tumor necrosis factor (TNF)- $\alpha$ antagonists, such as infliximab (IFX), etanercept (ETN), adalimumab (ADA), golimumab (GOLI) and certolizumab pegol (CZP) have been widely used for the treatment of RA. IFX provides significant, clinically relevant improvement in physical function and the quality of life, inhibits progressive joint damage and sustains improvement in the signs and symptoms of patients with RA. ETN is effective and safe for patients with RA. Combination therapy with ETN plus methotrexate (MTX) reduces disease activity, decreases total joint score progression, slows the pace of joint destruction and improves function more effectively compared to any of the monotherapies. ADA with or without MTX also relieves the signs and symptoms of RA. CZP and GOLI expand the therapeutic schedule for patients with RA. The TNF- $\alpha$ inhibitors have similar efficacy, but distinct clinical pharmacokinetic and-dynamic properties. The common adverse events of these TNF- $\alpha$ antagonists include adverse reactions, infections and injection-site reaction. Additionally, these adverse events are mostly mild or moderate and their incidence is low. Certain patients exhibit a lack of response to anti-TNF- $\alpha$ therapies. Some patients may discontinue the initial drug and switch to a second anti-TNF- $\alpha$ agent. The shortage of clinical response to one agent may not predict deficiency of response to another. This review mainly addresses the latest developments of these biological agents in the treatment of RA.
\end{abstract}

\section{Contents}

1. Introduction

2. TNF- $\alpha$ antagonist

Correspondence to: Professor Shengqian Xu, Department of Rheumatology and Immunology, The First Affiliated Hospital of Anhui Medical University, 218 Jixi Road, Hefei 230022, P.R. China E-mail: xsqian-1112@163.com

Key words: rheumatoid arthritis, immunotherapy, biological agent
3. Infliximab

4. Etanercept

5. Adalimumab

6. Golimumab

7. Certolizumab pegol

8. Similarity and difference between anti-TNF agents

9. Switching between various anti-TNF agents

10. Conclusions

\section{Introduction}

Rheumatoid arthritis (RA) is a chronic inflammatory disease characterized by progressive joint destruction. As joints deteriorate, patients suffer from pain and loss of function, often accompanied by decreasing quality of life and increasing mortality (1). Depending on the severity of the disease at onset, the risk of disability may be up to $30 \%$, and mortality can be increased by up to $52 \%$, frequently as a result of infection or circulatory disease (2).

RA treatment aims to minimize disease activity, thereby preventing or controlling joint damage and reducing the risk of other serious co-morbidities, such as heart disease or stroke. Early intervention is vital in patients with confirmed RA to preserve joint function (3-5).

Non-steroidal anti-inflammatory drugs (NSAIDs) and glucocorticoids are used to control pain and the inflammatory process (6). Following the diagnosis of RA, patients receive disease-modifying antirheumatic drugs (DMARDs), which reduce the signs and symptoms of the disease, and potentially inhibit radiographic progression (6). While a number of RA patients respond to DMARDs, a large proportion of RA remains active despite such treatments. The approach of targeting cytokines has considerably improved the success in the treatment of RA. In the clinical application, five tumor necrosis factor (TNF)- $\alpha$ inhibitors are available: infliximab (IFX), etanercept (ETN), adalimumab (ADA) (7-10), golimumab (GOLI) and certolizumab pegol (CZP).

This review focuses on the development of these agents regarding their effects on symptoms evaluated by the American College of Rheumatology (ACR) response criteria, structure (in the light of the erosion, joint-space narrowing and Sharp scores), and physical function [based on standardized questionnaires, such as the Health Assessment Questionnaire (HAQ)]. 
Table I. Comparison of clinical and radiographic response to IFX plus MTX.

\begin{tabular}{|c|c|c|c|c|c|c|}
\hline Authors (Ref.) & Groups & $\begin{array}{l}\text { Disease duration } \\
\quad \text { (weeks) }\end{array}$ & ACR20 & ACR50 & ACR70 & $\begin{array}{l}\text { vdH-S score } \\
(\text { Mean } \pm \text { SD) }\end{array}$ \\
\hline St. Clair, et al (16) & $\begin{array}{l}\text { IFX } 3 \text { mg + MTX } \\
\text { IFX } 6 \text { mg + MTX } \\
\text { PBO + MTX }\end{array}$ & 54 & $\begin{array}{l}62.4 \\
66.2 \\
53.6\end{array}$ & $\begin{array}{l}45.6 \\
50.4 \\
32.1\end{array}$ & $\begin{array}{l}32.5 \\
37.2 \\
21.2\end{array}$ & $\begin{array}{l}0.4 \pm 5.8 \\
0.5 \pm 5.6 \\
3.7 \pm 9.6\end{array}$ \\
\hline Maini, et al (17) & $\begin{array}{l}\text { IFX } 3 \mathrm{mg}+\text { MTX } \\
\text { q8 week } \\
\text { q4 week } \\
\text { IFX } 10 \mathrm{mg}+\text { MTX } \\
\text { q8 week } \\
\text { q4 week } \\
\text { PBO + MTX }\end{array}$ & 102 & $\begin{array}{l}48 \\
40 \\
16\end{array}$ & $\begin{array}{c}36 \\
20 \\
6\end{array}$ & $\begin{array}{l}20 \\
10 \\
1\end{array}$ & $\begin{array}{c}1.02 \pm 7.13 \\
1.03 \pm 11.65 \\
1.14 \pm 4.92 \\
-0.42 \pm 6.10 \\
12.59 \pm 20.05\end{array}$ \\
\hline Takeuchi, et al (18) & $\begin{array}{l}\text { IFX } 3 \mathrm{mg}+\text { MTX } \\
\text { IFX } 6 \mathrm{mg}+\text { MTX } \\
\text { IFX } 10 \mathrm{mg}+\text { MTX }\end{array}$ & 54 & $\begin{array}{l}75.8 \\
78.8 \\
82.7\end{array}$ & $\begin{array}{l}60.6 \\
58.7 \\
66.3\end{array}$ & $\begin{array}{l}37.4 \\
42.3 \\
43.3\end{array}$ & \\
\hline
\end{tabular}

IFX, infliximab; MTX, methotrexate; ACR, American College of Rheumatology; vdH-S, van der Heijde modification of the total Sharp score; $\mathrm{PBO}$, placebo; SD, standard deviation.

\section{TNF- $\alpha$ antagonist}

TNF- $\alpha$ is a significant cytokine that mediates inflammation in RA. Elevation of TNF- $\alpha$ levels have been observed in synovial fluid and the synovium of patients with RA (11). TNF- $\alpha$ plays an extremely central role in driving inflammation and bone degradation (12). Due to its influence on various cells in synovial membrane, such as synoviocytes, macrophages, chondrocytes and osteoclasts, which are able to produce metalloproteinases, collagenase and stromelysin, TNF- $\alpha$ induces local inflammation and pannus formation, eventually leading to further erosion of cartilage and bone destruction. Introduction of TNF- $\alpha$ inhibitors has revolutionized RA treatment options resulting in the development of further biologic DMARDs (13). The effects of a TNF- $\alpha$ blockade are partially dependent on synovial TNF- $\alpha$ expression and infiltration by TNF- $\alpha$-producing inflammatory cells (14). The progress in biotechnology contributes to the development of biological agents, such as anti-TNF- $\alpha$ monoclonal antibodies, as a strategy for the treatment of chronic inflammatory diseases.

\section{Infliximab}

IFX is a recombinant IgG1 monoclonal antibody specific for TNF- $\alpha$ that hinders the cytokine from triggering the cellular TNF receptor complex (15). IFX needs to be administered by intravenous infusion and has a terminal half-life of 8-10 days. Thus, it is administered every 4-8 weeks and the dosage varies from 3 to 6 (to 10$) \mathrm{mg} / \mathrm{kg}$.

The efficacy of IFX with MTX was previously demonstrated in several trials (Table I). Patients receiving combination therapy exhibited evidently higher median improvements compared to patients in the MTX plus placebo (PBO) group (16-18). In addition, the clinical efficacy was similar at varying dosages in the IFX group (16-18). In terms of radiographic images, the combination of IFX plus MTX prevented the radiographic progression and led to lasting clinical amelioration (16). IFX treatment inhibited joint damage progression even in patients who did not receive MTX in the RISING study (18). Compared to the MTX-only-treated patients, erosions and joint space narrowing evidently reduced from baseline in the IFX plus MTX-treated patients, with the exception of IFX $3 \mathrm{mg} / \mathrm{kg}$ every 8 weeks. There were fewer newly eroded joints per patient in the IFX plus MTX treatment groups compared to the MTX-only group (17). In their study, St. Clair et al demonstrated that HAQ scores showed improvement in the IFX group compared to the group receiving MTX alone (16).

The most common adverse events found in clinical trials of IFX are infusion reactions and infection. The therapy of IFX might increase the risk of malignancies and cardiovascular conditions (19). The incidence of serious infections, acute infusion reactions and death was similar in patients treated with IFX plus MTX and those who received MTX only (17). Among the serious infections, pneumonia and tuberculosis occurred more frequently in the IFX-treated patients compared to those treated with MTX alone $(16,19)$.

\section{Etanercept}

ETN is a genetically engineered protein comprising two molecules of the extracellular domain of TNF receptor II (p75) and the Fc portion of IgG1 (20). Due to its half-life of 3-5.5 days, ETN is administered subcutaneously (s.c), either on a weekly basis $(50 \mathrm{mg})$ or twice a week $(25 \mathrm{mg})(21)$.

The superiority of the combination therapy of ETN plus MTX over ETN or MTX monotherapy in patients with RA has been demonstrated (Table II) (22-24). The 2-year data from the TEMPO study confirmed that a larger proportion of patients treated with combination therapy exhibited clinical response compared to those receiving either ETN or MTX monotherapy (22). Moreover, the combination-treated patients had predominantly lower erosion change scores (-0.67) compared 
Table II. Comparison of clinical and radiographic response to ETN plus MTX and monotherapy.

\begin{tabular}{|c|c|c|c|c|c|c|c|}
\hline Authors (Ref.) & Groups & $\begin{array}{l}\text { Disease duration } \\
\text { (weeks) }\end{array}$ & ACR20 & ACR50 & ACR70 & $\begin{array}{l}\text { DAS28 } \\
<2.6(\%)\end{array}$ & $\begin{array}{c}\text { TTS } \\
\text { (Mean) }\end{array}$ \\
\hline \multirow[t]{3}{*}{ van der Heijde, et al (22) } & $\mathrm{ETN}+\mathrm{MTX}$ & 100 & 86 & 71 & 49 & 42.4 & -0.56 \\
\hline & ETN & & 75 & 54 & 27 & 22.4 & 1.10 \\
\hline & MTX & & 71 & 42 & 21 & 18.9 & 3.34 \\
\hline \multirow[t]{6}{*}{ Kavanaugh, et al (23) } & $\mathrm{ETN}+\mathrm{MTX}$ & 24 & & & & & -1.35 \\
\hline & ETN & & & & & & -0.19 \\
\hline & MTX & & & & & & 2.82 \\
\hline & $\mathrm{ETN}+\mathrm{MTX}$ & 54 & 81.0 & 83.8 & 82.6 & & \\
\hline & ETN & & 70.8 & 88.5 & 66.7 & & \\
\hline & MTX & & 62.2 & 50.0 & 63.2 & & \\
\hline \multirow[t]{2}{*}{ Kameda, et al (24) } & $\mathrm{ETN}+\mathrm{MTX}$ & 24 & 90.4 & 64.4 & 38.4 & 27.4 & \\
\hline & ETN & & 63.8 & 47.8 & 26.1 & 10.1 & \\
\hline
\end{tabular}

ETN, etanercept; MTX, methotrexate; ACR, American College of Rheumatology; DAS28, DAS in 28 joints; TTS, total sharp score.

Table III. Comparison of clinical and radiographic response to ADA plus MTX and monotherapy.

\begin{tabular}{|c|c|c|c|c|c|c|c|}
\hline Authors (Ref.) & Groups & $\begin{array}{l}\text { Disease duration } \\
\text { (weeks) }\end{array}$ & ACR20 & ACR50 & ACR70 & $\begin{array}{l}\text { DAS28 } \\
<2.6(\%)\end{array}$ & $\begin{array}{c}\text { TTS } \\
(\text { Mean } \pm \text { SD })\end{array}$ \\
\hline Kavanaugh, et al (32) & $\begin{array}{l}\mathrm{ADA}+\mathrm{MTX} \\
\mathrm{PBO}+\mathrm{MTX}\end{array}$ & 26 & $\begin{array}{l}70 \\
57\end{array}$ & $\begin{array}{l}52 \\
34\end{array}$ & $\begin{array}{l}35 \\
17\end{array}$ & $\begin{array}{l}34 \\
17\end{array}$ & \\
\hline Keystone, et al (33) & $\begin{array}{l}\text { ADA } 40 \mathrm{mg}+\mathrm{MTX} \\
\text { ADA } 20 \mathrm{mg}+\mathrm{MTX} \\
\mathrm{PBO}+\mathrm{MTX}\end{array}$ & 52 & $\begin{array}{l}58.9 \\
54.7 \\
24.0\end{array}$ & $\begin{array}{l}41.5 \\
37.7 \\
9.5\end{array}$ & $\begin{array}{l}23.2 \\
20.8 \\
4.5\end{array}$ & & $\begin{array}{l}0.1 \pm 4.8 \\
0.8 \pm 4.9 \\
2.7 \pm 6.8\end{array}$ \\
\hline
\end{tabular}

ADA, adalimumab; MTX, methotrexate; ACR, American College of Rheumatology; DAS28, DAS in 28 joints; PBO, placebo; TTS, total sharp score; SD, standard deviation.

to patients treated with ETN (0.39) or MTX (3.25) alone (25). Therefore, treatment with a combination of ETN and MTX stopped joint damage and patients exhibited disease remission (25). Sustained efficacy and decreased rate of radiographic progression was observed in patients with early aggressive RA who underwent long-term treatment with ETN (26). Patients adopting combination therapy enhanced to a greater extent in function status compared to those in the monotherapy group (27). Additionally, ETN (50 mg) once weekly was an optimal treatment in most patients with RA. Increasing the dosage of ETN from $50 \mathrm{mg}$ once a week to $50 \mathrm{mg}$ twice a week in suboptimal responders did not markedly improve response rates (28). With regard to safety and efficacy, no obvious improvement was observed between ETN as monotherapy at 50 and $25 \mathrm{mg}$ twice weekly (29).

Injection-site reactions and hypertension were more common with ETN compared to MTX or combination therapy (22). These events were mostly mild or moderate. Nausea and vomiting were more often associated with MTX compared to ETN or combination therapy. No statistically significant differences were observed in the groups regarding the incidence of serious adverse events (infectious and non-infectious) (22).

Thus, ETN is beneficial for patients with RA. However, the combination of ETN with MTX is superior to a mono- therapy with each drug. The combination regimen may reduce disease activity, retard radiographic progression and improve function. Furthermore, the treatment with ETN plus MTX is well-tolerated and does not increase serious adverse events.

\section{Adalimumab}

ADA is a monoclonal antibody of recombinant immunoglobulin (IgG1) containing only human sequences of peptides. It is an antagonist of TNF- $\alpha$, which is able to prevent the binding of TNF- $\alpha$ to its receptors (6). It has a half-life of 10-20 days and may be used as monotherapy or in combination with several other DMARDs, preferably MTX (30-31). The recommended dose of ADA is $25 \mathrm{mg}$ s.c. twice a week.

Treatment with ADA plus MTX was found to be statistically superior to PBO plus MTX, according to the ACR20/50/70 response rates at week 26 (Table III) (32). When receiving ADA plus MTX in early RA, patients exhibited rapid clinical and functional improvements (32). ADA regimens decreased the risk of radiographic disease progression (33). In a 5-year, open-label extension study, the addition of ADA led to greater inhibition of structural damage compared to patients who continued with MTX monotherapy (Table III) (34). The PREMIER study confirmed that treatment with ADA plus 
Table IV. Comparison of clinical and radiographic response to GOLI plus MTX and monotherapy.

\begin{tabular}{|c|c|c|c|c|c|c|}
\hline Authors (Ref.) & Groups & $\begin{array}{l}\text { Disease duration } \\
\quad \text { (weeks) }\end{array}$ & ACR20 & ACR50 & ACR70 & $\begin{array}{l}\text { DAS28 } \\
(\text { Mean } \pm \text { SD) }\end{array}$ \\
\hline Keystone, et al (37) & $\begin{array}{l}\text { GOLI } 50 \mathrm{mg}+\text { MTX } \\
\text { GOLI } 100 \mathrm{mg}+\text { MTX } \\
\text { GOLI } 100 \mathrm{mg}+\text { PBO } \\
\text { PBO + MTX }\end{array}$ & 24 & $\begin{array}{l}59.6 \\
59.6 \\
35.3 \\
27.8\end{array}$ & $\begin{array}{l}37.1 \\
32.6 \\
19.5 \\
13.5\end{array}$ & $\begin{array}{r}20.2 \\
14.6 \\
11.3 \\
5.3\end{array}$ & \\
\hline Kay, et al (39) & $\begin{array}{l}\text { GOLI + MTX } \\
50 \text { mg (every } 4 \text { weeks) } \\
50 \text { mg (every } 2 \text { weeks) } \\
100 \text { mg (every } 4 \text { weeks) } \\
100 \text { mg (every } 2 \text { weeks) } \\
\text { PBO + MTX }\end{array}$ & 16 & $\begin{array}{l}60.0 \\
50.0 \\
55.9 \\
79.4 \\
37.1\end{array}$ & $\begin{array}{r}37.1 \\
23.5 \\
29.4 \\
32.4 \\
5.7\end{array}$ & $\begin{array}{r}8.6 \\
14.7 \\
17.6 \\
8.8 \\
0.0\end{array}$ & $\begin{array}{l}-1.9 \pm 1.3 \\
-1.4 \pm 1.3 \\
-1.9 \pm 1.5 \\
-1.9 \pm 1.1 \\
-0.9 \pm 1.0\end{array}$ \\
\hline Weinblatt, et al (40) & $\begin{array}{l}\text { GOLI } 2 \mathrm{mg} / \mathrm{kg}+\mathrm{MTX} \\
\mathrm{PBO}+\mathrm{MTX}\end{array}$ & 16 & $\begin{array}{l}58.5^{\mathrm{a}} \\
24.9\end{array}$ & $\begin{array}{l}34.9 \\
13.2\end{array}$ & $\begin{array}{r}17.7 \\
4.1\end{array}$ & $\begin{array}{l}-2.0 \pm 1.40 \\
-0.7 \pm 1.35\end{array}$ \\
\hline
\end{tabular}

MTX, methotrexate; ACR, American College of Rheumatology; DAS28, DAS in 28 joints; GOLI, golimumab; PBO, placebo; SD, standard deviation. ${ }^{\mathrm{a}} \mathrm{ACR} 20$ response was observed at week 14.

MTX initiated earlier contributed to higher improvements in clinical, functional and radiographic responses as compared to treatment with MTX or ADA alone (35). In addition, ADA plus MTX ameliorated physical function for patients with RA $(33,36)$

ADA exhibited a good overall tolerance. Findings of a previous study demonstrated that the rate of adverse events (serious and nonserious) was similar in the ADA and PBO groups, although the proportion of patients reporting serious infections was higher in patients receiving ADA $(3.8 \%)$ compared to those receiving PBO $(0.5 \%)(\mathrm{P}<0.02)$, and was the highest in the patients administered $40 \mathrm{mg}$ every other week (33). The common adverse events were injection site reactions and serious infections, such as military tuberculosis and cellulitis (35). However, ADA was safe and well-tolerated. Adverse events were not serious and severe side effects were relatively seldom.

\section{Golimumab}

GOLI is a human anti-TNF- $\alpha$ monoclonal antibody that is generated and matured in an in vivo system (37). GOLI has a high affinity and specificity for human TNF- $\alpha$ and effectively neutralizes TNF- $\alpha$ bioactivity in vitro (38).

The efficacy of GOLI has been demonstrated in several groups (Table IV) (37,39-40). The combination of GOLI and MTX was significantly better at improving the signs and symptoms of RA and physical function (37). No difference has been observed in the efficacy between the two GOLI dose groups (50 and $100 \mathrm{mg}$ ) (37). Compared individually with the PBO group, GOLI in combination with MTX in patients with RA showed greater clinical response, while the response rates did not show a clear dose-response pattern in the groups of GOLI plus MTX (Table IV) (39).

In the multicenter, randomized, PBO-controlled GO-FORWARD study, the mean improvement from baseline in HAQ-DI was significantly greater for GOLI $50 \mathrm{mg}+$ MTX and
100 mg + MTX vs. PBO + MTX (41). However, GOLI + MTX also elicited a significant better response compared to $\mathrm{PBO}+\mathrm{MTX}$ in various efficacy parameters, including disease activity score (DAS28) response. Additionally, the combination of GOLI and MTX limited radiographic progression (42).

The safety of GOLI was demonstrated in various trials (39-41). However, adverse events were reported in the process of treatment. The most frequent adverse events in the combined GOLI groups were nausea, headache and injection site reaction (39-41). Most events were mild or moderate (43). In general, GOLI in combination with MTX may alleviate the signs and symptoms of RA and improve physical function.

\section{Certolizumab pegol}

CZP is a humanized anti-TNF- $\alpha$ antibody with high affinity to TNF- $\alpha$ (44). In managing patients with RA, the recommended dose of CZP is $400 \mathrm{mg}$ (given as two s.c. injections of $200 \mathrm{mg}$ ) initially and at weeks 2 and 4, followed by $200 \mathrm{mg}$ every other week.

An international, multicenter, phase 3, randomized, double-blind, PBO-controlled study had assessed the efficacy of CZP in RA patients for MTX non-responders (45). Compared to PBO treatment, CZP plus MTX effectively reduced the signs and symptoms of RA, and inhibited progression of joint damage (Table V) (45-46). No evident differences were observed in clinical efficacy between the two CZP dose groups (45). Additionally, treatment with CZP monotherapy also provided a rapid, meaningful and durable clinical response and acceptable safety profile (Table V) (47). Increasing the CZP dose from 200 to $400 \mathrm{mg}$ did not result in an additional benefit in RA patients (48). A study showed that the mean tender joint count (-24.8 vs. -24.6) or swollen joint count (-18.6 vs. -18.7) was similar between the dose-escalation (200 $\mathrm{mg}$ increased to $400 \mathrm{mg}$ every other week) and stable-dose subgroups (400 mg every other week) (49). The most common adverse reactions were 
Table V. Comparison of clinical and radiographic response to CZP plus MTX and monotherapy.

\begin{tabular}{llcccccc}
\hline Authors (Ref.) & \multicolumn{1}{c}{ Groups } & $\begin{array}{c}\text { Disease duration } \\
\text { (weeks) }\end{array}$ & ACR20 & ACR50 & ACR70 & $\begin{array}{l}\text { mTTS } \\
\text { (Mean) }\end{array}$ & $\begin{array}{c}\text { DAS } \\
\text { (Mean } \pm \text { SD) }\end{array}$ \\
\hline Smolen, et al (45) & CZP 200 mg + MTX & 24 & 57.3 & 32.5 & 15.9 & 0.2 & $-2.27(1.38)$ \\
& CZP 400 mg + MTX & & 57.6 & 32.5 & 10.6 & -0.4 & $-2.46(1.31)$ \\
& PBO + MTX & & 8.7 & 33.1 & 0.8 & 1.2 & $-0.50(1.05)$ \\
Keystone, et al (46) & CZP 200 mg & 24 & 58.8 & 37.1 & 21.4 & & $-3.3 \pm 1.3$ \\
& CZP 400 mg + MTX & & 60.8 & 39.9 & 20.6 & & $-3.4 \pm 1.4$ \\
& PBO + MTX & & 13.6 & 7.6 & 3.0 & $-2.4 \pm 1.3$ \\
Fleischmann, et al (47) & CZP 400 mg & 24 & 45.4 & 22.7 & 5.5 & -1.5 \\
& PBO & & 9.3 & 3.7 & 0.0 & & -0.6 \\
\hline
\end{tabular}

CZP, certolizumab pegol; MTX, methotrexate; ACR, American College of Rheumatology; DAS28, DAS in 28 joints; mTTS, modified total sharp score; $\mathrm{PBO}$, placebo; SD, standard deviation.

Table VI. Clinical responses after 6 and 12 months of treatment: values given as percentage.

\begin{tabular}{|c|c|c|c|c|c|c|c|c|}
\hline \multirow[b]{2}{*}{ Variables } & \multicolumn{2}{|c|}{ ADA (months) } & \multicolumn{2}{|c|}{ ETN (months) } & \multicolumn{2}{|c|}{ IFX (months) } & \multicolumn{2}{|c|}{ P-value (months) } \\
\hline & 6 & 12 & 6 & 12 & 6 & 12 & 6 & 12 \\
\hline \multicolumn{9}{|l|}{ EULAR response } \\
\hline No. of patients & 536 & 444 & 414 & 377 & 889 & 690 & & \\
\hline Good & 52 & 57 & 42 & 49 & 34 & 40 & $<0.0001$ & $<0.0001$ \\
\hline Moderate & 33 & 30 & 39 & 32 & 38 & 39 & & \\
\hline No response & 15 & 12 & 19 & 20 & 29 & 21 & & \\
\hline \multicolumn{9}{|l|}{ DAS28 remission } \\
\hline No. of patients & 536 & 444 & 414 & 377 & 889 & 690 & & \\
\hline Remission & 32 & 39 & 26 & 33 & 21 & 27 & $<0.0001$ & $<0.0001$ \\
\hline LUNDEX corrected & 26 & 27 & 21 & 24 & 17 & 16 & $<0.0001$ & $<0.0001$ \\
\hline \multicolumn{9}{|l|}{ ACR response } \\
\hline No. of patients & 519 & 426 & 383 & 346 & 852 & 660 & & \\
\hline ACR50 & 45 & 53 & 40 & 45 & 31 & 38 & $<0.0001$ & $<0.0001$ \\
\hline ACR70 & 24 & 30 & 21 & 27 & 14 & 17 & $<0.0001$ & $<0.0001$ \\
\hline
\end{tabular}

EULAR, European League Against Rheumatism; ACR, American College of Rheumatology; DAS28, DAS in 28 joints; ADA, adalimumab; IFX, infliximab; ETN, etanercept.

Table VII. Switching between various anti-TNF agents.

\begin{tabular}{|c|c|c|}
\hline Clinical end-point & IFX & ETN \\
\hline ACR20 response $(\%)$ & 61.5 & 28.6 \\
\hline ACR50 response $(\%)$ & 30.7 & 14.3 \\
\hline \multicolumn{3}{|l|}{ DAS28 } \\
\hline Mean $( \pm$ SD) & $4.0(1.5)$ & $5.2(1.6)$ \\
\hline$\%$ change from baseline & $-30.8(28.6)$ & $-16.0(24.2)$ \\
\hline Patients with DAS28 score $<2.6(\%)$ & 15.4 & 7.1 \\
\hline Patients with HAQ decrease $>0.22(\%)$ & 61.5 & 14.3 \\
\hline Patients with HAQ decrease $>0.40(\%)$ & 38.5 & 0.0 \\
\hline
\end{tabular}


tuberculosis, injection site pain and injection site reaction (46).

As shown above, CZP monotherapy or the combination therapy with MTX as an effective treatment provides a rapid, meaningful and durable clinical response and an acceptable safety profile.

\section{Similarity and difference between anti-TNF agents}

It is widely accepted that patients with RA have low quality of life. Clinical trials have shown that TNF- $\alpha$ blocking agents, such as ETN, IFX and ADA, relieve joint inflammations and slow the radiographic progression of joint damage and improve physical function in advanced RA (50-52). The availability of newer agents, including CZP and GOLI, has increased treatment options for patients with RA. Furthermore, anti-TNF- $\alpha$ agents are more efficacious in promoting the clinical signs and symptoms of RA compared to MTX alone. Anti-TNF- $\alpha$ agents plus MTX show sustained efficacy and remain more effective compared to anti-TNF- $\alpha$ monotherapy (53). Compared to MTX and PBO, the ACR20, 50 and 70 response rates for 1-year treatment with MTX plus any of the TNF inhibitors were 60 vs. $25 \%, 40$ vs. $10 \%$ and 20 vs. $5 \%$, respectively (54).

However, they have distinct clinical pharmacokinetic and -dynamic properties that must be considered when selecting one drug for therapy (55). For example, there are evident differences in the half-lives of the three agents (IFX, ETN and ADA), with ETN having the shortest (3-5.5 days) and ADA the longest ( 2 weeks) (21). The three types of biological agents also differ from each other in their dosing regimens (55). The larger, yet less frequently administered dose of IFX may result in higher peak serum concentrations compared to the smaller but more commonly administered dose of ETN and ADA, resulting in higher tissue concentrations (55). Total efficacies of varying biologics are highly similar, which have been observed in most of the studies and adopted by several investigators (55). Nevertheless, a recent study indicated significant differences in the efficacy of and adherence to therapy with ADA, ETN and IFX (56). IFX had the lowest treatment responses, disease remission and drug adherence rates. ADA had the highest treatment response and remission rate, while ETN had the longest drug survival rate (56) (Table VI).

In their study, Singh et al (57) demonstrated that patients administered ADA plus IFX were at a markedly higher risk compared to those administered PBO. Indirect companies showed that ADA had a higher tendency to withdraw compared to ETN (OR 1.89; 95\% CI, 1.18-3.04) and ETN was less likely than IFX (OR 0.37; 95\% CI, 0.19-0.70). Additionally, there seemed to be differences in the risk of tuberculosis (TB) among varying biologics, and this might influence the selection of patients likely to receive the biological agent. TB occurred more frequently in monoclonal antibodies-treated patients (i.e., IFX and ADA) compared to those treated with soluble TNF receptor therapy (i.e., ETN) (58-59). The rate of hospitalized infection in patients treated with other agents was lower compared to that for patients treated with IFX (60). Among these biological agents, the incidence of serious infections was higher in the CZP group compared to others. ADA , ETN and GOLI were associated with a low incidence of treatment discontinuation due to adverse events, whereas the IFX was not (61). Moreover, the biological agents increased the risk of infections. Consequently, patients with tuberculosis should be excluded and should receive pneumococcal, influenza and hepatitis $\mathrm{B}$ vaccinations prior to undergoing the therapy with biological agents.

\section{Switching between various anti-TNF agents}

Patients with RA may discontinue their initial drug and switch to a second anti-TNF- $\alpha$ agent due to shortage of drug efficacy. Regarding the effect of the second biological agent, in a retrospective study (62), certain patients $(n=20)$ switched from ETN to IFX, while others $(n=73)$ received IFX with no prior anti-TNF- $\alpha$ therapy. The C-reactive protein, swollen and tender joint counts as well as the morning stiffness ameliorated in the two groups, while no statistically significant difference was observed in the degree of benefit between the groups (62). However, IFX may be of additional clinical profit for patients with an incomplete response to ETN. In particular, patients receiving IFX exhibited a better amelioration in the HAQ score compared to those receiving ETN (Table VII) (63).

Another study concluded that patients switching to ADA exhibited a good clinical response when the therapy of IFX or ETN was ineffective (64). Patients who do not respond to an initial anti-TNF drug may also improve their HAQ score, subsequent to switching to a second agent (65). Patients with RA may be successfully treated with another TNF- $\alpha$ agent, especially those withdrawing due to inefficacy and adverse events (66). The above results demonstrated that switching among various biological agents was beneficial.

\section{Conclusions}

Biological agents render the treatment of RA a new era, especially for patients with an insufficient response to DMARDs. Biological agents can quickly relieve clinical symptoms and delay bone destruction. When the TNF- $\alpha$ inhibitors are applied in clinical practice, the combination with DMARDs are conductive to ease the symptoms and prevent bone structural damage and elevate physical function. Moreover, the conversion between various agents may have the same function. Certain drugs, such as ETN, in combination with MTX are better compared to monotherapy regarding long-term efficacy. Most adverse events of agents are infection-site reactions. Although severe side-effects may be treated appropriately, they still prevent clinical remedy. Physicians should prescribe various treatment regimens according to the patient's symptoms as well as constantly explore the immune mechanism of RA, and develop novel biological agents. In the future, immunotherapy is likely to bring fundamental changes for patients with RA.

\section{References}

1. Nanke Y, Kotake S, Akama H and Kamatani N: Alkaline phosphatase in rheumatoid arthritis patients: possible contribution of bone-type ALP to the raised activities of ALP in rheumatoid arthritis patients. Clin Rheumatol 21: 198-202, 2002.

2. Mikuls TR, Saag KG, Criswell LA, et al: Mortality risk associated with rheumatoid arthritis in a prospective cohort of older women: results from the Iowa Women's Health Study. Ann Rheum Dis 61: 994-999, 2002. 
3. Kremer JM, Russell AS, Emery P, et al: Long-term safety, efficacy and inhibition of radiographic progression with abatacept treatment in patients with rheumatoid arthritis and an inadequate response to methotrexate: 3-year results from the AIM trial. Ann Rheum Dis 70: 1826-1830, 2011.

4. Keystone E, Freundlich B, Schiff M, Li J and Hooper M: Patients with moderate rheumatoid arthritis (RA) achieve better disease activity states with etanercept treatment than patients with severe RA. J Rheumatol 36: 522-531, 2009.

5. Baumgartner SW, Fleischmann RM, Moreland LW, et al: Etanercept (Enbrel) in patients with rheumatoid arthritis with recent onset versus established disease: improvement in disability. J Rheumatol 31: 1532-1537, 2004.

6. Wiens A, Correr CJ, Venson R, Otuki MF and Pontarolo R: A systematic review and meta-analysis of the efficacy and safety of adalimumab for treating rheumatoid arthritis. Rheumatol Int 30 : 1063-1070, 2010

7. Smolen JS, Han C, Bala M, et al: ATTRACT Study Group. Evidence of radiographic benefit of treatment with infliximab plus methotrexate in rheumatoid arthritis patients who had no clinical improvement: a detailed subanalysis of data from the anti-tumor necrosis factor trial in rheumatoid arthritis with concomitant therapy study. Arthritis Rheum 52: 1020-1030, 2005.

8. Gao GH, Li J, Xie HW and Lü Z: Therapeutic effect of infliximab on moderate and severe active rheumatoid arthritis. Nan Fang Yi Ke Da Xue Xue Bao 30: 724-726, 2010 (In Chinese).

9. Mathias SDDColwell HHDMiller DPDet al: Health-related quality of life and functional status of patients with rheumatoid arthritis randomly assigned to receive etanercept or placebo. Clin Ther 22: 128-139, 2000.

10. Breedveld FC, Weisman MH,Kavanaugh AF, et al: The PREMIER study: A multicenter, randomized, double-blind clinical trial of combination therapy with adalimumab plus methotrexate versus methotrexate alone or adalimumab alone in patients with early, aggressive rheumatoid arthritis who had not had previous methotrexate treatment. Arthritis Rheum 54: 26-37, 2006.

11. Fütterer A, Mink K, Luz A, Kosco-Vilbois MH and Pfeffer K The lymphotoxin beta receptor controls organogenesis and affinity maturation in peripheral lymphoid tissues. Immunity 9: 59-70, 1998.

12. Visvanathan S, Rahman MU, Keystone E, et al: Association of serum markers with improvement in clinical response measures after treatment with golimumab in patients with active rheumatoid arthritis despite receiving methotrexate: results from the GO-FORWARD study. Arthritis Res Ther 12: R211, 2010.

13. Kleinert S, Tony HP, Krause A, et al: Impact of patient and disease characteristics on therapeutic success during adalimumab treatment of patients with rheumatoid arthritis: data from a German noninterventional observational study. Rheumatol Int 32: 2759-2767, 2012

14. Wijbrandts CA, Dijkgraaf MG, Kraan MC, et al: The clinical response to infliximab in rheumatoid arthritis is in part dependent on pretreatment tumour necrosis factor alpha expression in the synovium. Ann Rheum Dis 67: 1139-1144, 2008.

15. Feldmann M, Elliott MJ, Woody JN and Maini RN: Anti-tumor necrosis factor-alpha therapy of rheumatoid arthritis. Adv Immunol 64: 283-350, 1997.

16. St. Clair EW, van der Heijde DM, Smolen JS, et al: Active-controlled study of patients receiving infliximab for the treatment of rheumatoid arthritis of early onset study group. Combination of infliximab and methotrexate therapy for early rheumatoid arthritis: a randomized, controlled trial. Arthritis Rheum 50: 3432-3443, 2004

17. Maini RN,Breedveld FC, Kalden JR, et al: Sustained improvement over two years in physical function, structural damage, and signs and symptoms among patients with rheumatoid arthritis treated with infliximab and methotrexate. Arthritis Rheum 50: $1051-1065,2004$

18. Takeuchi T, Miyasaka N, Inoue K, Abe T and Koike T: RISING study: Impact of trough serum level on radiographic and clinical response to infliximab plus methotrexate in patients with rheumatoid arthritis: results from the RISING study. Mod Rheumatol 19: 478-487, 2009.

19. Delabaye I, De Keyser F and REMITRACT study group: 74-week follow-up of safety of infliximab in patients with refractory rheumatoid arthritis. Arthritis Res Ther 12: R121, 2010.

20. Moreland LW, Baumgartner SW, Schiff MH, et al: Treatment of rheumatoid arthritis with a recombinant human tumor necrosis factor receptor(p75)-Fc fusion protein. N Engl J Med 337: 141-147, 1997.
21. Saag KG, Teng GG, Patkar NM, et al: American College of Rheumatology. American College of Rheumatology 2008 recommendations for the use of nonbiologic and biologic disease-modifying antirheumatic drugs in rheumatoid arthritis. Arthritis Rheum 59: 762-784, 2008.

22. van der Heijde D, Klareskog L, Rodriguez-Valverde V, et al: TEMPO Study Investigators. Comparison of etanercept and methotrexate, alone and combined, in the treatment of rheumatoid arthritis: two-year clinical and radiographic results from the TEMPO study, a double-blind, randomized trial. Arthritis Rheum 54: 1063-1074, 2006.

23. Kavanaugh A, Klareskog L, van der Heijde D, et al: Improvements in clinical response between 12 and 24 weeks in patients withrheumatoid arthritis on etanercept therapy with or without methotrexate. Ann Rheum Dis 67: 1444-1447, 2008.

24. Kameda H, Ueki Y, Saito K, et al: Japan Biological Agent Study Integrated Consortium. Etanercept (ETN) with methotrexate (MTX) is better than ETN monotherapy in patients with active rheumatoid arthritis despite MTX therapy: a randomized trial. Mod Rheumatol 20: 531-538, 2010.

25. van der Heijde D, Klareskog L, Landewé R, et al: Disease remission and sustained halting of radiographic progression with combination etanercept and methotrexate in patients with rheumatoid arthritis. Arthritis Rheum 56: 3928-3939, 2007.

26. Genovese MC, Bathon JM, Fleischmann RM, et al: Longterm safety, efficacy, and radiographic outcome with etanercept treatment in patients with early rheumatoid arthritis. J Rheumatol 32: 1232-1242, 2005

27. van der Heijde D, Klareskog L, Singh A, et al: Patient-reported outcomes in a trial of combination therapy with etanercept and methotrexate for rheumatoid arthritis: the TEMPO trial. Ann Rheum Dis 65: 328-334, 2006.

28. Weinblatt ME, Schiff MH, Ruderman EM, et al: Efficacy and safety of etanercept $50 \mathrm{mg}$ twice a week in patients with rheumatoid arthritis who had a suboptimal response to etanercept $50 \mathrm{mg}$ once a week: results of a multicenter, randomized, double-blind, active drug-controlled study. Arthritis Rheum 58: 1921-1930, 2008

29. Johnsen AK, Schiff MH, Mease PJ, et al: Comparison of 2 doses of etanercept (50 vs $100 \mathrm{mg}$ ) in active rheumatoid arthritis: a randomized double blind study. J Rheumatol 33: 659-664, 2006.

30. van de Putte LB, Atkins C, Malaise M, et al: Efficacy and safety of adalimumab as monotherapy in patients with rheumatoid arthritis for whom previous disease-modifying antirheumatic drug treatment has failed. Ann Rheum Dis 63: 508-516, 2004.

31. Furst DE, Schiff MH, Fleischmann RM, et al: Adalimumab, a fully human anti tumor necrosis factor-alpha monoclonal antibody, and concomitant standard antirheumatic therapy for the treatment of rheumatoid arthritis: results of STAR (Safety Trial of Adalimumab in Rheumatoid Arthritis). J Rheumatol 30: 2563-2571, 2003.

32. Kavanaugh A, Fleischmann RM, Emery P, et al: Clinical, functional and radiographic consequences of achieving stable low disease activity and remission with adalimumab plus methotrexate or methotrexate alone in early rheumatoid arthritis: 26-week results from the randomised, controlled OPTIMA study. Ann Rheum Dis: May 19, 2012 (Epub ahead of print).

33. Keystone EC, Kavanaugh AF, Sharp JT, et al: Radiographic, clinical, and functional outcomes of treatment with adalimumab (a human anti-tumor necrosis factor monoclonal antibody) in patients with active rheumatoid arthritis receiving concomitant methotrexate therapy: a randomized, placebo-controlled, 52-week trial. Arthritis Rheum 50: 1400-1411, 2004.

34. Keystone EC, Kavanaugh A, Weinblatt ME, Patra K and Pangan AL: Clinical consequences of delayed addition of adalimumab to methotrexate therapy over 5 years in patients with rheumatoid arthritis. J Rheumatol 38: 855-862, 2011.

35. Takeuchi T, Tanaka Y, Kaneko Y, et al: Effectiveness and safety of adalimumab in Japanese patients with rheumatoid arthritis: retrospective analyses of data collected during the first year of adalimumab treatment in routine clinical practice (HARMONY study). Mod Rheumatol 22: 327-338, 2012.

36. Strand V, Rentz AM, Cifaldi MA, et al: Health-related quality of life outcomes of adalimumab for patients with early rheumatoid arthritis: results from a randomized multicenter study. J Rheumatol 39: 63-72, 2012

37. Keystone EC, Genovese MC, Klareskog L, et al: Golimumab, a human antibody to tumour necrosis factor \{alpha\} given by monthly subcutaneous injections, in active rheumatoid arthritis despite methotrexate therapy: the GO-FORWARD Study. Ann Rheum Dis 68: 789-796, 2009. 
38. Shealy D, Cai A, Staquet K, et al: Characterization of golimumab, a human monoclonal antibody specific for human tumor necrosis factor alpha. MAbs 2: 428-439, 2010.

39. Kay J, Matteson EL, Dasgupta B, et al: Golimumab in patients with active rheumatoid arthritis despite treatment with methotrexate: a randomized, double-blind, placebo-controlled, dose-ranging study. Arthritis Rheum 58: 964-975, 2008.

40. Weinblatt ME, Bingham CO III, Mendelsohn AM, et al: Intravenous golimumab is effective in patients with active rheumatoid arthritis despite methotrexate therapy with responses as early as week 2: results of the phase 3 , randomised, multicentre, double-blind, placebo-controlled GO-FURTHER trial. Ann Rheum Dis: Jun 1,2012 (Epub ahead of print).

41. Genovese MC, Han C, Keystone EC, et al: Effect of golimumab on patient-reported outcomes in rheumatoid arthritis: Results from the GO-FORWARD Study. J Rheumatol 39: 1185-1191, 2012.

42. Tanaka Y, Harigai M, Takeuchi T, et al: the GO-FORTH Study Group. Golimumab in combination with methotrexate in Japanese patients with active rheumatoid arthritis: results of the GO-FORTH study. Ann Rheum Dis 71: 817-824, 2012.

43. Emery P, Fleischmann RM, Moreland LW, et al: Golimumab, a human anti-tumor necrosis factor alpha monoclonal antibody, injected subcutaneously every four weeks in methotrexate-naive patients with active rheumatoid arthritis: twenty-four-week results of a phase III, multicenter, randomized, double-blind, placebo-controlled study of golimumab before methotrexate as first-line therapy for early-onset rheumatoid arthritis. Arthritis Rheum 60: 2272-2283, 2009.

44. Nesbitt A, Fossati G, Bergin M, et al: Mechanism of action of certolizumab pegol (CDP870): in vitro comparison with other anti-tumor necrosis factor alpha agents. Inflamm Bowel Dis 13: 1323-1332, 2007.

45. Smolen J, Landewe RB, Mease P, et al: Efficacy and safety of certolizumab pegol plus methotrexate in active rheumatoid arthritis: the RAPID 2 study. A randomised controlled trial. Ann Rheum Dis 68: 797-804, 2009.

46. Keystone E, Heijde D, Mason D Jr, et al: Certolizumab pegol plus methotrexate is significantly more effective than placebo plus methotrexate in active rheumatoid arthritis: findings of a fifty-two-week, phase III, multicenter, randomized, double-blind, placebo-controlled, parallel-group study. Arthritis Rheum 58: 3319-3329, 2008

47. Fleischmann R, Vencovsky J, van Vollenhoven RF, et al: Efficacy and safety of certolizumab pegol monotherapy every 4 weeks in patients with rheumatoid arthritis failing previous disease-modifying antirheumatic therapy: the FAST4WARD study. Ann Rheum Dis 68: 805-811, 2009.

48. Keystone EC, Combe B, Smolen J, et al: Sustained efficacy of certolizumab pegol added to methotrexate in the treatment of rheumatoid arthritis: 2-year results from the RAPID 1 trial. Rheumatology (Oxford) 51: 1628-1638, 2012.

49. Curtis JR, Chen L, Luijtens K, et al: Dose escalation of certolizumab pegol from $200 \mathrm{mg}$ to $400 \mathrm{mg}$ every other week provides no additional efficacy in rheumatoid arthritis: an analysis of individual patient-level data. Arthritis Rheum 63: 2203-2208, 2011.

50. Kekow J, Moots RJ, Emery P, et al: Patient-reported outcomes improve with etanercept plus methotrexate in active early rheumatoid arthritis and the improvement is strongly associated with remission: The COMET trial. Ann Rheum Dis 69: 222-225, 2010.

51. Weinblatt ME, Kremer JM, Bankhurst AD, et al: A trial of etanercept, a recombinant tumor necrosis factor receptor: $\mathrm{Fc}$ fusion protein, in patients with rheumatoid arthritis receiving methotrexate. N Engl J Med 340: 253-259, 1999.
52. Haraoui B, Cividino A, Stewart J, Guérette B and Keystone EC: Safety and effectiveness of adalimumab in a clinical setting that reflects Canadian standard of care for the treatment of rheumatoid arthritis (RA): results from the CanACT study. BMC Musculoskelet Disord 12: 261-270, 2011.

53. Aaltonen KJ, Virkki LM, Malmivaara A, et al: Systematic review and meta-analysis of the efficacy and safety of existing TNF blocking agents in treatment of rheumatoid arthritis. PLoS One 7: e30275, 2012

54. Caporali R, Pallavicini FB, Filippini M, et al: Treatment of rheumatoid arthritis with anti-TNF-alpha agents: a reappraisal. Autoimmun Rev 8: 274-280, 2009.

55. Hyrich KL, Lunt M, Watson KD, Symmons DP, Silman AJ and British Society for Rheumatology Biologics Register: Outcomes after switching from one anti-tumor necrosis factor alpha agent to a second anti-tumor necrosis factor alpha agent in patients with rheumatoid arthritis: results from a large UK national cohort study. Arthritis Rheum 56: 13-20, 2007.

56. Hetland ML, Christensen IJ, Tarp U, et al: Direct comparison of treatment responses, remission rates, and drug adherence in patients with rheumatoid arthritis treated with adalimumab, etanercept, or infliximab: results from eight years of surveillance of clinical practice in the nationwide Danish DANBIO registry. Arthritis Rheum 62: 22-32, 2010.

57. Singh JA, Christensen R, Wells GA, et al: Biologics for rheumatoid arthritis: an overview of Cochrane reviews. Sao Paulo Med J 128: 309-310, 2010

58. Fonseca JE, Canhão H, Silva C, et al: Grupo de Estudos de Artrite Reumatóide da Sociedade Portuguesa de Reumatologia. Tuberculosis in rheumatic patients treated with tumour necrosis factor alpha antagonists: the Portuguese experience. Acta Reumatol Port 31: 247-253, 2006 (In Portuguese).

59. Nam JL, Winthrop KL, van Vollenhoven RF, et al: Current evidence for the management of rheumatoid arthritis with biological disease-modifying antirheumatic drugs: a systematic literature review informing the EULAR recommendations for the management of RA. Ann Rheum Dis 69: 976-986, 2010.

60. Curtis JR, Xie F, Chen L, et al: The comparative risk of serious infections among rheumatoid arthritis patients starting or switching biological agents. Ann Rheum Dis 70: 1401-1406, 2011.

61. Singh JA, Wells GA, Christensen R, et al: Adverse effects of biologics: a network meta-analysis and Cochrane overview. Cochrane Database Syst Rev 16: CD008794, 2011.

62. Hansen KE, Hildebrand JP, Genovese MC, et al: The efficacy of switching from etanercept to infliximab in patients with rheumatoid arthritis. J Rheumatol 31: 1098-1102, 2004.

63. Furst DE, Gaylis N, Bray V, et al: Open-label, pilot protocol of patients with rheumatoid arthritis who switch to infliximab after an incomplete response to etanercept: the opposite study. Ann Rheum Dis 66: 893-899, 2007.

64. Wick MC, Ernestam S, Lindblad S, et al: Adalimumab (Humira) restores clinical response in patients with secondary loss of efficacy from infliximab (Remicade) or etanercept (Enbrel): results from the STURE registry at Karolinska University Hospital. Scand J Rheumatol 34: 353-358, 2005.

65. Hyrich KL, Lunt M, Dixon WG, Watson KD, Symmons DP and BSR Biologics Register: Effects of switching between anti-TNF therapies on HAQ response in patients who do not respond to their first anti-TNF drug. Rheumatology (Oxford) 47: 1000-1005, 2008.

66. Scrivo R, Conti F, Spinelli FR, et al: Switching between TNFalpha antagonists in rheumatoid arthritis: personal experience and review of the literature. Reumatismo 61: 107-117, 2009. 